\title{
Microstructure Evolution and Mechanical Properties of a Directionally Solidified Nb-Ti-Si-Cr-Al-Hf-Dy Alloy
}

\author{
Liyuan $\mathrm{SHENG}^{1, *}$ \\ ${ }^{1}$ Shenzhen Insititute, Peking University, Shenzhen 518057, China
}

\begin{abstract}
The Nb-Ti-Si-Cr-Al-Hf-Dy alloy was prepared by conventionally casting and then directionally solidified (DS) with the optical floating zone melting technology. Microstructural evolution and mechanical properties of the as cast (AC) and DS alloys were studied by XRD, SEM, TEM, compression and bending tests. The results exhibit that $\alpha-(\mathrm{Nb}, \mathrm{Ti})_{5} \mathrm{Si}_{3},(\mathrm{Ti}, \mathrm{Nb})_{5} \mathrm{Si}_{3}$ and $(\mathrm{Nb}, \mathrm{Ti})$ ss phases formed the microstructure of the AC alloy, with precipitates of $\mathrm{Cr}_{2} \mathrm{Nb}, \mathrm{Dy}_{2} \mathrm{O}_{3}$ and $(\mathrm{Nb}, \mathrm{Ti})_{3} \mathrm{Si}$ along phase or grain boundaries. The DS alignes $(\mathrm{Nb}, \mathrm{Ti}) \mathrm{ss}$ and $\alpha-(\mathrm{Nb}, \mathrm{Ti})_{5} \mathrm{Si}_{3}$ lamellae parallel to the growth direction and refines the eutectic cell, but coarsens the primary $\alpha-(\mathrm{Nb}, \mathrm{Ti})_{5} \mathrm{Si}_{3}$ phase. The DS alloy exhibits strong orientation of $(310)_{(\mathrm{Nb}, \mathrm{Ti}) 5 \mathrm{Si} 3}$ and $(110)_{(\mathrm{Nb}, \mathrm{Ti}) \mathrm{ss}}$ along the growth direction. TEM observation reveals that $(\mathrm{Nb}, \mathrm{Ti}) \mathrm{ss}$ and $\alpha-(\mathrm{Nb}, \mathrm{Ti})_{5} \mathrm{Si}_{3}$ phases have an orientation relationship of $[110]_{(\mathrm{Nb}, \mathrm{Ti}) \mathrm{ss}} / /[310]_{\alpha-(\mathrm{Nb}, \mathrm{Ti}) 5 \mathrm{Si} 3}$ and $(002)_{(\mathrm{Nb}, \mathrm{Ti}) \mathrm{ss}} / /$ $(002)_{\alpha-(\mathrm{Nb}, \mathrm{Ti}) 5 \mathrm{Si} 3}$. Compared with the AC alloy, the DS increases the mechanical properties of the alloy obviously and the alloy DS at $8 \mathrm{~mm} / \mathrm{h}$ exhibits the best mechanical properties.
\end{abstract}

\section{Introduction}

Intermetallic compounds have been paid much attention recently, due to their excellent properties in some aspects [1-3]. As one type of high-temperature intermetallic compound, niobium silicide possesses many superiorities, such as excellent high-temperature creep strength and high melting point (about $2793 \mathrm{~K}$ ) [4,5]. Therefore, the niobium silicide has been thought as a potential material to apply in super high-temperature environment. However, the poor oxidation resistance and undesired room-temperature fracture toughness restrict its industrial application. To solve these problems, many methods have been applied and some niobium silicide based alloys have been developed [6-7]. Among these alloys, the $\mathrm{Nb}-\mathrm{Ti}-\mathrm{Si}-\mathrm{Cr}-\mathrm{Al}-\mathrm{Hf}$ alloy is the most promising one which makes use of the $\mathrm{Nb}$ solid solution (Nbss) ductile phase as the matrix and the $\mathrm{Nb}_{5} \mathrm{Si}_{3}$ as strengthening phase [8]. Due to the relative low high-temperature strength of Nbss, the massive presence of Nbss would be detrimental to the high-temperature property. Then, to take full use of the strength of $\mathrm{Nb}_{5} \mathrm{Si}_{3}$

* Corresponding author: lysheng@yeah.net 
and ductility of Nbss, the Nbss and $\mathrm{Nb}_{5} \mathrm{Si}_{3}$ phases should be arranged as an alternative lamellar structure. Moreover the precipitation of $\mathrm{NbCr}_{2}$ Laves phase is also detrimental to the fracture toughness. Therefore, the optimization on the morphology and distribution of these stiffness phases is important, which could help to increase the mechanical property. Based on recent researches [9-11], the rare earth element could scavenge impurities and refine grain boundary, which could increase the fracture toughness further. Therefore, in the present research trace Dy has been added in the $\mathrm{Nb}$-Ti-Si-Cr-Al-Hf alloy. In order to obtain an $\mathrm{Nbss} / \mathrm{Nb}_{5} \mathrm{Si}_{3}$ alternative lamellar structure, the $\mathrm{Nb}$-Ti-Si-Cr-Al-Hf-Dy alloy has been directionally solidified (DS) with the optical floating zone melting technique. Microstructure evolution and mechanical property improvement of the DS alloy are studied.

\section{Experimental}

The alloy vacuum arc melting technology was employed to fabricate the alloy with nominal composition of Nb-22Ti-16Si-7Cr-3Al-2Hf-0.1Dy (at.\%) from pure metal niobium (99.9\%), titanium (99.9\%), silicon (99.9\%), chromium (99.9), aluminum $(99.9 \%)$, hafnium (99.8\%) and dysprosium (99.8\%). A part of the obtained alloy ingot was studied at the as cast (AC) state and the other was left for the DS process. The electro-discharge machining (EDM) was applied to cut the DS rods from the alloy ingot and their dimensions are $\Phi 8 \mathrm{~mm} \times 80 \mathrm{~mm}$. The DS process is carried out on the optical floating zone furnace (OFZ), which adopted the high-energy visible light to remelt the alloy rod and synchronous rotation to guarantee the uniform and orderly melting. Three growth rates of 5,8 and $11 \mathrm{~mm} / \mathrm{h}$ were applied on the present the DS alloy.

Microstructural characterisations of the AC and DS alloys were performed by Phenom ${ }^{\mathrm{TM}}$ Pro scanning electron microscopy (SEM). The Bruker D8 X-ray diffraction (XRD) with a Cu Karadiation was employed to analyze the phases at $40 \mathrm{kV}$ and $40 \mathrm{~mA}$. Constitute phase composition in the alloy was analyzed by the EPMA-1610 electronic probe microanalysis. The specimen for transmission electron microscope (TEM) characterization was cut from the $\mathrm{AC}$ and DS alloys with thickness of $0.4 \mathrm{~mm}$. Then the specimen was polished to $30 \mu \mathrm{m}$ and shaped into $\varphi 3 \mathrm{~mm}$ in size followed by twin-jet electropolishing. TEM analyses were carried out on the JEOL-2100 high-resolution transmission electron microscope (HRTEM). Compression sample $\left(4 \times 4 \times 6 \mathrm{~mm}^{3}\right)$ was cut from the AC and DS alloys and mechanical grounded by 800 -grit $\mathrm{SiC}$ abrasive. Gleeble 3800 was employed to carry out the compression test at strain rate of $2 \times 10^{-3} / \mathrm{s}$. Fracture toughness was obtained by the three-point bending test. The bending test specimens were cut along the DS growth direction to get the lamella structure perpendicular to the force direction. The size of the bending test specimen is $3 \mathrm{~mm}$ $\times 6 \mathrm{~mm} \times 30 \mathrm{~mm}$ with a $3 \mathrm{~mm}$ notch in middle.

\section{Results and Discussion}

Backscattered electron SEM micrographs of the AC Nb-Ti-Si-Cr-Al-Hf-Dy alloy are presented in Fig. 1 (a) and (b). It could be found that the microstructure of the AC alloy primarily comprises four kinds of phases. According to recent research [8], the gray-white matrix should be $(\mathrm{Nb}, \mathrm{Ti})$ ss phase and gray phase should be $\alpha-(\mathrm{Nb}, \mathrm{Ti})_{5} \mathrm{Si}_{3}$. The $(\mathrm{Nb}, \mathrm{Ti}) \mathrm{ss}$ and $\alpha-(\mathrm{Nb}, \mathrm{Ti})_{5} \mathrm{Si}_{3}$ phases form the eutectic structure with the embellishment with of black $(\mathrm{Ti}, \mathrm{Nb})_{5} \mathrm{Si}_{3}$ phase and some white particles. Moreover, the microstructure shows coarse $\alpha-(\mathrm{Nb}, \mathrm{Ti})_{5} \mathrm{Si}_{3}$ dendrite. The black $(\mathrm{Ti}, \mathrm{Nb})_{5} \mathrm{Si}_{3}$ phases prefer to precipitate along the eutectic cell boundary and form the semi-continuously necklace shape. White particles prefer to precipitate along phase and grain boundary, but its distribution is random. XRD analysis on the AC alloy exhibits that the $(\mathrm{Ti}, \mathrm{Nb})_{5} \mathrm{Si}_{3}, \alpha-(\mathrm{Nb}, \mathrm{Ti})_{5} \mathrm{Si}_{3}$ and $(\mathrm{Nb}, \mathrm{Ti}) \mathrm{ss}$ phases are main 
constituents, see Fig.1 (c). XRD analysis shows the $\alpha-(\mathrm{Nb}, \mathrm{Ti})_{5} \mathrm{Si}_{3}$ phase possesses the I4/mcm crystal structure $\left(\mathrm{Cr}_{5} \mathrm{~B}_{3}\right.$ type $)$ and its amount is higher than that of the $(\mathrm{Ti}, \mathrm{Nb})_{5} \mathrm{Si}_{3}$ phase. Additionally, the phases with different crystal orientation exhibit homogenisation tendency in the AC alloy. TEM analysis and selected area diffraction pattern (SADP) on the white phase confirm it to be $\mathrm{Dy}_{2} \mathrm{O}_{3}$ oxide, which owns a hexagonal crystal structure $(\mathrm{a}=\mathrm{b}=$ $3.82 \mathrm{~nm}, \mathrm{c}=6.11 \mathrm{~nm}$ ) and the space group of P-3ml, as presented in Fig.1 (d). The formation of this kind of oxide should be attributed to the activity of the rare earth Dy, which could capture the oxygen atom to form the oxide. Such behaviour is helpful to improve the adhesion of grain boundary. Further TEM observation also reveals the small $\mathrm{Cr}_{2} \mathrm{Nb}$ phase along the $\alpha-(\mathrm{Nb}, \mathrm{Ti})_{5} \mathrm{Si}_{3} /(\mathrm{Nb}, \mathrm{Ti})$ ss phase interface, as presented in Fig.1 (e). The SADP reveals that it possesses the C14 crystal structure. Due to the high stiffness of this kind of phase, its precipitation along grain boundary would result in stress concentration and microcrack propagation, which is detrimental to the fracture toughness. Because the formation of $\mathrm{Cr}_{2} \mathrm{Nb}$ phase is related to the element segregation, the change of solidification mode could help to eliminate this kind of phase. In addition, it is still found that there are some metastable $(\mathrm{Nb}, \mathrm{Ti})_{3} \mathrm{Si}$ phases along the eutectic cell boundaries, as shown in Fig.1 (f). Moreover, an orientation relationship between the $(\mathrm{Nb}, \mathrm{Ti})$ ss phase and the $(\mathrm{Nb}, \mathrm{Ti})_{3} \mathrm{Si}$ phase can be described as: $[112]_{(\mathrm{Nb}, \mathrm{Ti}) \mathrm{ss}} / /[001]_{(\mathrm{Nb}, \mathrm{Ti}) 3 \mathrm{Si}}$ and $(110)_{(\mathrm{Nb}, \mathrm{Ti}) \mathrm{ss}} / /(110)_{(\mathrm{Nb}, \mathrm{Ti}) 3 \mathrm{Si}}$. The presence of this kind of phase should be ascribed to the solidification rate and element segregation.
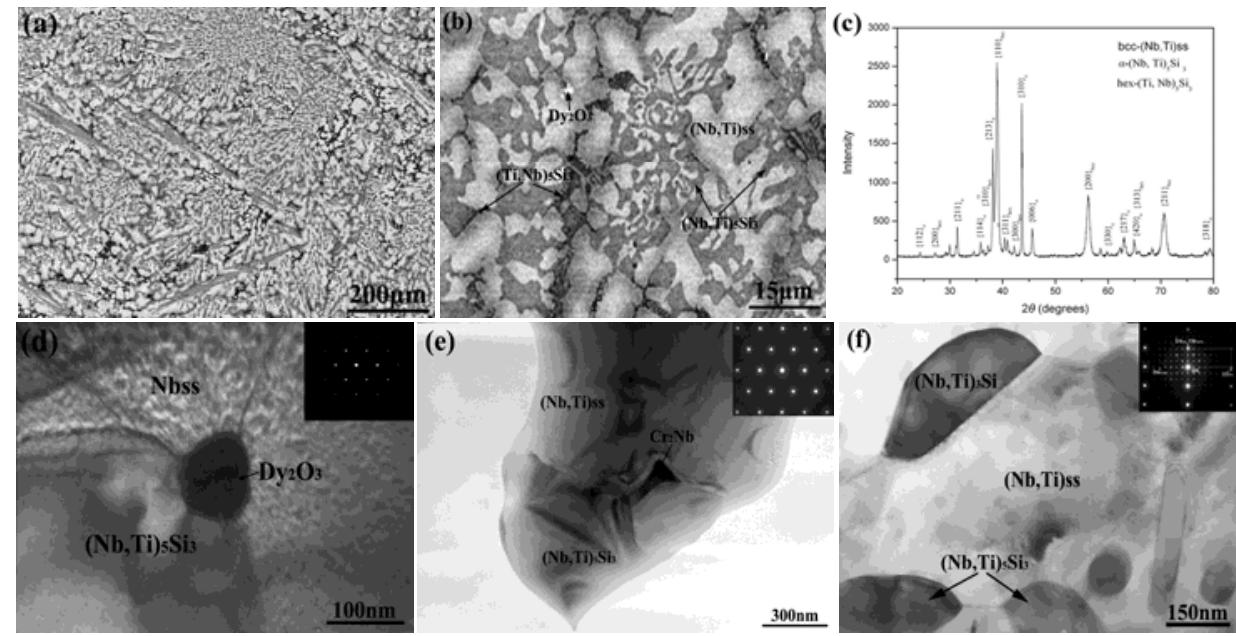

Fig.1 (a) Backscattered SEM micrograph of the AC alloy, (b) Precipitates along the eutectic cell boundary, (c) $\mathrm{X}$-ray diffraction pattern of the $\mathrm{AC}$ alloy, (d) TEM micrograph of the $\mathrm{Dy}_{2} \mathrm{O}_{3}$ precipitate (Inset image exhibiting the $\mathrm{SADP}$ of the $\mathrm{Dy}_{2} \mathrm{O}_{3}$ precipitate), (e) Morphology of the $\mathrm{Cr}_{2} \mathrm{Nb}$ phase along (Nb,Ti)ss $/ \alpha-(\mathrm{Nb}, \mathrm{Ti})_{5} \mathrm{Si}_{3}$ interface (Inset image exhibiting the SADP of the $\mathrm{Cr}_{2} \mathrm{Nb}$ phase), (f) TEM micrograph of the (Nb,Ti) ${ }_{3}$ Si phase (Inset image exhibiting the composite SADP of the (Nb,Ti)ss and $(\mathrm{Nb}, \mathrm{Ti})_{3} \mathrm{Si}$ phases)

SEM observations on the microstructure of the Nb-Ti-Si-Cr-Al-Hf-Dy alloy DS at different growth rate are exhibited in Fig.2. Clearly, the DS process has changed the microstructure of the alloy greatly. Different from the AC alloy, the DS alloy mainly exhibits the $\alpha$-(Nb,Ti) $)_{5} \mathrm{Si}_{3} /(\mathrm{Nb}, \mathrm{Ti})$ ss alternative lamellar structure, as shown in Fig.2 (a)-(f). The DS also make the alloy possesses smaller eutectic cells but coarser primary $\alpha-(\mathrm{Nb}, \mathrm{Ti})_{5} \mathrm{Si}_{3}$. Moreover, the amount of $(\mathrm{Ti}, \mathrm{Nb})_{5} \mathrm{Si}_{3}$ has increased obviously, especially at lower growth rate. When the growth rate increases, the amount of primary $\alpha-(\mathrm{Nb}, \mathrm{Ti})_{5} \mathrm{Si}_{3}$ increases gradually, but its size becomes smaller. It is interesting that the $(\mathrm{Ti}, \mathrm{Nb})_{5} \mathrm{Si}_{3}$ participates in the eutectic structure formation at $5 \mathrm{~mm} / \mathrm{h}$ but just segregates along eutectic cell boundary at 8 and $11 \mathrm{~mm} / \mathrm{h}$. Furthermore, the amount of $(\mathrm{Ti}, \mathrm{Nb})_{5} \mathrm{Si}_{3}$ seems to decrease, with growth rate 
increase. In addition, the distribution of $\mathrm{Dy}_{2} \mathrm{O}_{3}$ particle becomes more uniform. With the increase of the growth rate, it can be observed that the microstructure become finer and the coarse $\alpha-(\mathrm{Nb}, \mathrm{Ti})_{5} \mathrm{Si}_{3}$ phase tends to decrease. Further observation shows that the interphase spacing and the intercellular boundary width reduce obviously. When the growth rate increase to $11 \mathrm{~mm} / \mathrm{h}$, the fine $\alpha-(\mathrm{Nb}, \mathrm{Ti})_{5} \mathrm{Si}_{3} /(\mathrm{Nb}, \mathrm{Ti}) \mathrm{ss}$ eutectic structure forms along the coarse $\alpha-(\mathrm{Nb}, \mathrm{Ti})_{5} \mathrm{Si}_{3}$ and $(\mathrm{Nb}, \mathrm{Ti})$ ss lamellae. However, the formation of discontinuous silicide and transversal dendrites would destroy the lamellae structure and deteriorate the mechanical property. Among all DS alloys, the one DS at 5 and $8 \mathrm{~mm} / \mathrm{h}$ has the desired microstructure.

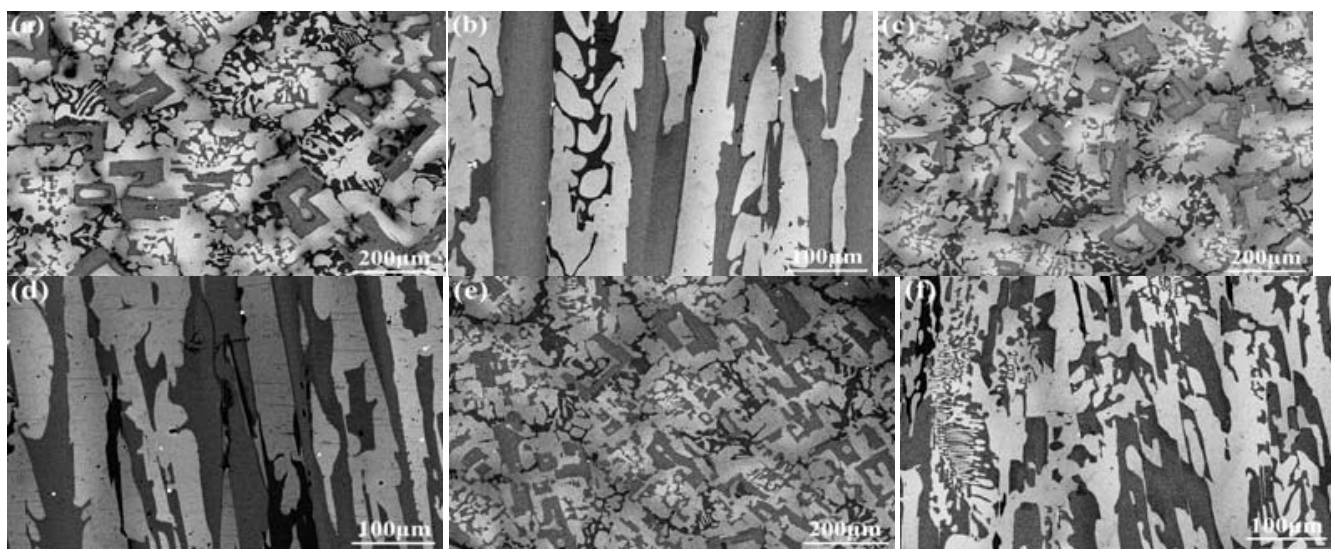

Fig.2 SEM image of the transverse microstructure (a, c, e) and longitudinal microstructure (b, d, f) of the $\mathrm{Nb}$-Ti-Si-Cr-Al-Hf-Dy alloy DS at growth rate of $5 \mathrm{~mm} / \mathrm{h}(\mathrm{a}, \mathrm{b}), 8 \mathrm{~mm} / \mathrm{h}(\mathrm{c}, \mathrm{d}), 11 \mathrm{~mm} / \mathrm{h}(\mathrm{e}, \mathrm{f})$

Thought the microstructures of the DS alloys have some difference, they almost have the same tendency. Therefore, the DS alloy at $8 \mathrm{~mm} / \mathrm{h}$ was chosen to perform the further characterization. XRD analysis on the DS alloy is presented in Fig.3 (a). The section vertical to the growth direction is chosen as the tested surface. Compared with the XRD of AC alloy, the DS alloy exhibits strong orientation of $(310)_{\alpha-(\mathrm{Nb}, \mathrm{Ti}) 5 \mathrm{Si} 3}$ and $(110)_{(\mathrm{Nb}, \mathrm{Ti}) \mathrm{ss}}$ along the DS direction, but the $\mathrm{AC}$ alloy exhibits scattered orientations. It indicates that the $(310)_{\alpha-(\mathrm{Nb}, \mathrm{Ti}) 5 \mathrm{Si} 3}$ and $(110)_{(\mathrm{Nb}, \mathrm{Ti}) \mathrm{ss}}$ are the preferential orientation of the alloy during the DS. TEM observation on the DS alloy confirms the XRD results. The typical TEM image of the $\alpha-(\mathrm{Nb}, \mathrm{Ti})_{5} \mathrm{Si}_{3} /(\mathrm{Nb}, \mathrm{Ti}) \mathrm{ss}$ eutectic lamellar structure is shown in Fig.3 (b). In the eutectic structure, the $\alpha-(\mathrm{Nb}, \mathrm{Ti})_{5} \mathrm{Si}_{3}$ and $(\mathrm{Nb}, \mathrm{Ti})$ ss lamellae aligns alternately. The width of the $\alpha-(\mathrm{Nb}, \mathrm{Ti})_{5} \mathrm{Si}_{3}$ lamella is $2.5 \sim 3 \mu \mathrm{m}$ and that of $(\mathrm{Nb}, \mathrm{Ti}) \mathrm{ss}$ about $2 \mu \mathrm{m}$. From the composite SADP, the orientation relationship of the $\alpha-(\mathrm{Nb}, \mathrm{Ti})_{5} \mathrm{Si}_{3} /(\mathrm{Nb}, \mathrm{Ti})$ ss eutectic can be described as: $[110]_{(\mathrm{Nb}, \mathrm{Ti}) s s} / /[310]_{\alpha-(\mathrm{Nb}, \mathrm{Ti}) 5 \mathrm{Si} 3}$ and $(002)_{(\mathrm{Nb}, \mathrm{Ti}) s s} / /(002)_{\alpha-(\mathrm{Nb}, \mathrm{Ti}) 5 \mathrm{Si} 3}$. Furthermore, the HRTEM observation on the $\alpha-\left(\mathrm{Nb}, \mathrm{Ti}_{5} \mathrm{Si}_{3} /(\mathrm{Nb}, \mathrm{Ti}) \mathrm{ss}\right.$ eutectic interface has been carried out with the electron beam parallel to the $[310]_{\alpha-(\mathrm{Nb}, \mathrm{Ti}) 5 \mathrm{Si} 3}$. Fig. 3(c) exhibits the atom arrangement along the eutectic interface, which suggests that it is a good matching region. The image reveals no transition layer was formed in the interface. The interface is roughly parallel to the (002) lattice plane of the $\alpha-(\mathrm{Nb}, \mathrm{Ti})_{5} \mathrm{Si}_{3}$ and $(\mathrm{Nb}, \mathrm{Ti})$ ss phases, which indicates the $\alpha-(\mathrm{Nb}, \mathrm{Ti})_{5} \mathrm{Si}_{3}$ and $(\mathrm{Nb}, \mathrm{Ti}) \mathrm{ss}$ phases almost have the same growth rate during solidification process. It is also expected that a straight interface will reduce segregation of impurities to the interface and benefit to improving the interface cohesion. 
(a)

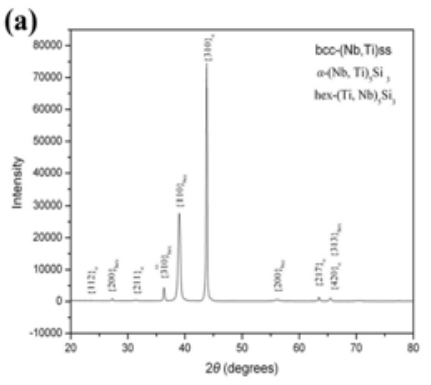

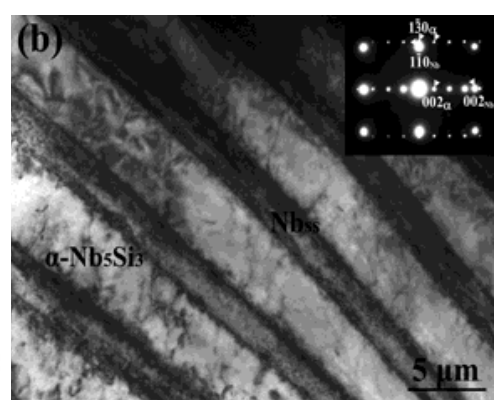

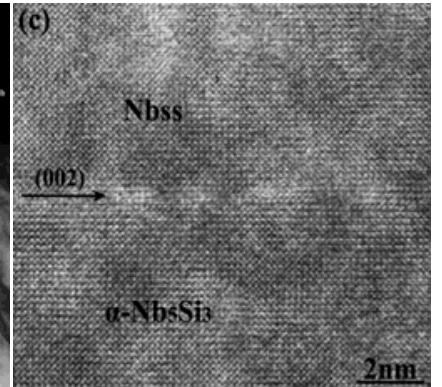

Fig.3 (a) X-ray diffractogram of the DS alloy at growth rate of $8 \mathrm{~mm} / \mathrm{h}$, (b) TEM morphology of the $\alpha-(\mathrm{Nb}, \mathrm{Ti})_{5} \mathrm{Si}_{3} /(\mathrm{Nb}, \mathrm{Ti})$ ss eutectic lamella (Inset image exhibiting the composite SADP), (c) HRTEM image of the $\alpha-(\mathrm{Nb}, \mathrm{Ti})_{5} \mathrm{Si}_{3} /(\mathrm{Nb}, \mathrm{Ti}) \mathrm{ss}$ phase interface viewed along the incident beam of $[310]_{\alpha-(\mathrm{Nb}, \mathrm{Ti}) 5 \mathrm{Si} 3}$

To evaluate the influence of DS process on the mechanical properties of the $\mathrm{Nb}$-Ti-Si-Cr-Al-Hf-Dy alloy, bending and compression tests were carried out at room temperature. The results of the fracture toughness and yield strength of the AC and DS alloys at room temperature are given in Table 1. Clearly, the DS process improves the mechanical properties of the alloy obviously. The fracture toughness and yield strength of the DS alloys are all higher than those of the AC alloy, especially the fracture toughness. Though the average value of the fracture toughness has a little fluctuation with DS growth rate, it still almost 30\% higher than that of the AC alloy. The fracture toughness reach the highest value in the alloy DS at $8 \mathrm{~mm} / \mathrm{h}$. Similar with the variation of fracture toughness, the DS alloy obtains the highest yield strength at growth rate of $8 \mathrm{~mm} / \mathrm{h}$. The improvement of the fracture toughness and yield strength should be ascribed to the microstructure optimization, because the morphology of the ductile phase could influence the mechanical property greatly $[12,13]$. As described above, the DS process aligns the $(\mathrm{Nb}, \mathrm{Ti}) \mathrm{ss}$ and $\alpha-(\mathrm{Nb}, \mathrm{Ti})_{5} \mathrm{Si}_{3}$ lamellae alternately, which could make full use of the ductility of the ( $\mathrm{Nb}, \mathrm{Ti}) \mathrm{ss}$ phase. The $(\mathrm{Nb}, \mathrm{Ti}) \mathrm{ss}$ lamellae could provide more opportunities for crack bridging and crack deflection and then increase the fracture toughness [14]. However the increased $(\mathrm{Ti}, \mathrm{Nb})_{5} \mathrm{Si}_{3}$ and coarse primary $\alpha-(\mathrm{Nb}, \mathrm{Ti})_{5} \mathrm{Si}_{3}$ could contribute to the strength improvement of the alloy. Therefore the DS alloy possesses better mechanical properties than the AC alloy. Due to the optimized microstructure, the alloy DS at $8 \mathrm{~mm} / \mathrm{h}$ has the best mechanical properties.

Table 1 Fracture Toughness And Yield Strength Of The Ac And Ds Alloys

\begin{tabular}{|c|c|c|c|}
\hline Alloy & $\begin{array}{c}\text { Growth rate } \\
(\mathrm{mm} / \mathrm{h})\end{array}$ & $\mathrm{K}_{\mathrm{Q}}\left(\mathrm{MPa} \cdot \mathrm{m}^{1 / 2}\right)$ & $\begin{array}{c}\text { Yield strength } \\
(\mathrm{MPa})\end{array}$ \\
\hline \multirow{2}{*}{$\mathrm{AC}$} & - & $10.9 \pm 0.7$ & $1780 \pm 19.6$ \\
\hline \multirow{2}{*}{$\mathrm{DS}$} & 5 & $13.1 \pm 0.3$ & $1885 \pm 13.2$ \\
\cline { 2 - 4 } & 8 & $13.3 \pm 0.2$ & $1950 \pm 12.1$ \\
\cline { 2 - 4 } & 11 & $12.8 \pm 0.4$ & $1900 \pm 14.6$ \\
\hline
\end{tabular}

\section{Conclusions}

(1) In the AC alloy, $\alpha-(\mathrm{Nb}, \mathrm{Ti})_{5} \mathrm{Si}_{3}$ phase, $(\mathrm{Ti}, \mathrm{Nb})_{5} \mathrm{Si}_{3}$ phase and $(\mathrm{Nb}, \mathrm{Ti})$ ss martrix form the main microstructure, with some $\mathrm{Cr}_{2} \mathrm{Nb},(\mathrm{Nb}, \mathrm{Ti})_{3} \mathrm{Si}$ and $\mathrm{Dy}_{2} \mathrm{O}_{3}$ particles present at the phase interfaces. 
(2) The DS aligns $(\mathrm{Nb}, \mathrm{Ti}) \mathrm{ss}$ and $\alpha-(\mathrm{Nb}, \mathrm{Ti})_{5} \mathrm{Si}_{3}$ lamella parallel to the growth direction and refines the eutectic cell, but coarse the primary $\alpha-(\mathrm{Nb}, \mathrm{Ti})_{5} \mathrm{Si}_{3}$ phase. The DS alloy exhibits strong orientation of $(310)_{\alpha-(\mathrm{Nb}, \mathrm{Ti}) 5 \mathrm{Si} 3}$ and $(110)_{(\mathrm{Nb}, \mathrm{Ti}) \mathrm{ss}}$ along the DS direction.

(3) TEM observation reveals that $(\mathrm{Nb}, \mathrm{Ti}) \mathrm{ss}$ and $\alpha-(\mathrm{Nb}, \mathrm{Ti})_{5} \mathrm{Si}_{3}$ phases have an orientation relationship of $[110]_{(\mathrm{Nb}, \mathrm{Ti}) \mathrm{ss}} / /[310]_{\alpha-(\mathrm{Nb}, \mathrm{Ti}) 5 \mathrm{Si} 3}$ and $(002)_{(\mathrm{Nb}, \mathrm{Ti}) \mathrm{ss}} / /(002)_{\alpha-(\mathrm{Nb}, \mathrm{Ti}) 5 \mathrm{Si} 3}$.

(4) The DS alloy possesses the better mechanical properties than the AC alloy. The alloy DS at $8 \mathrm{~mm} / \mathrm{h}$ exhibits the best mechanical properties.

\section{Acknowledgements}

The authors are grateful to the Shenzhen International Cooperative Research Project (GJHZ20140419114548516), the Strategic New Industry Development Special Foundation of Shenzhen (JCYJ20140419114548515 and JCYJ20140419114548513) and the Shenzhen Technology Innovation Plan (CXZZ20140419114548507 and CXZZ20140731091722497) for the financial support.

\section{References}

1. D.M. Shah, D.L. Anton, D.P. Pope, S. Chin, In-situ refractory intermetallic-based composites, Mater. Sci. Eng. A, 192-193 (1995) 658-672.

2. $\quad$ L.Y. Sheng, F. Yang, T.F. Xi, Y.F. Zheng and J.T. Guo, Microstructure and room temperature mechanical properties of NiAl-Cr(Mo)-(Hf, Dy) hypoeutectic alloy prepared by injection casting, Trans. Nonferrous Met. Soc. China, 23 (2013) 983-990.

3. L.Y. Sheng, F. Yang, J.T. Guo, T.F. Xi and H.Q. Ye, Investigation on NiAl-TiC- $\mathrm{Al}_{2} \mathrm{O}_{3}$ composite prepared by self-propagation high temperature synthesis with hot extrusion, Compos. Part B- Eng., 45 (2013) 785-791.

4. B.P. Bewlay, M.R. Jackson, J.-C. Zhao, P.R. Subramanian, M.G. Mendiratta, J.J. Lewandowski, Ultrahigh-temperature $\mathrm{Nb}$-silicide-based composites, MRS Bulletin, 28 (2003) 646-653.

5. J. Kajuch, J. Short, J.J. Lewandowski, Deformation and fracture behavior of $\mathrm{Nb}$ in $\mathrm{Nb}_{5} \mathrm{Si}_{3} / \mathrm{Nb}$ laminates and its effect on laminate toughness, Acta Metall. Mater., 43 (1995) 1955-1967.

6. J.-H. Kim, T. Tabaru, M. Sakamoto, S. Hanada, Mechanical properties and fracture behavior of an $\mathrm{Nbss} / \mathrm{Nb}_{5} \mathrm{Si}_{3}$ in-situ composite modified by Mo and $\mathrm{Hf}$ alloying, Mater. Sci. Eng. A, 372 (2004) 137-144.

7. J.B. Sha, H. Hirai, T.Tabaru, A. Kitahara, H. Ueno, S. Hanada, High temperature strength and room-temperature toughness of $\mathrm{Nb}-\mathrm{W}-\mathrm{Si}$-B alloys prepared by arc-melting, Mater. Sci. Eng. A, 364 (2003) 151-8.

8. K. Zelenitsas, P. Tsakiropoulos, Study of the role of $\mathrm{Ta}$ and $\mathrm{Cr}$ additions in the microstracture of Nb-Ti-Si-Al in situ composites, Intermetallics, 14 (2006) 639-659.

9. L.Y. Sheng, L.J. Wang, T.F. Xi, Y.F. Zheng, H.Q. Ye, Microstructure, precipitates and compressive properties of various holmium doped $\mathrm{NiAl} / \mathrm{Cr}(\mathrm{Mo}, \mathrm{Hf})$ eutectic alloys' Mater. Design, 32 (2011) 4810-4817.

10. L.Y. Sheng, J.T. Guo, Y.X. Tian, L.Z. Zhou and H.Q. Ye, Microstructure and mechanical properties of rapidly solidified NiAl-Cr(Mo) eutectic alloy doped with trace Dy, J. Alloy Comp., 475 (2009) 730-734.

11. L.Y. Sheng, W. Zhang, J.T. Guo, Z.S. Wang, H.Q. Ye, Microstructure evolution and elevated temperature compressive properties of a rapidly solidified $\mathrm{NiAl}-\mathrm{Cr}(\mathrm{Nb}) / \mathrm{Dy}$ alloy, Mater. Design, 30 (2009) 2752-2755. 
12. M.F. Ashby, F.J. Blunt, M. Bannister, Flow characteristics of highly constrained metal wires, Acta Metall., 37 (1989) 1847-1857.

13. L.Y. Sheng, W. Zhang, J.T. Guo, L.Z. Zhou and H.Q. Ye, Microstructure evolution and mechanical properties' improvement of NiAl-Cr(Mo)-Hf eutectic alloy during suction casting and subsequent HIP treatment, Intermetallics, 17 (2009) 1115-1119.

14. L.Y. Sheng, F. Yang, T.F. Xi, Y.F. Zheng and J.T. Guo, Improvement of compressive strength and ductility in $\mathrm{NiAl}-\mathrm{Cr}(\mathrm{Nb}) / \mathrm{Dy}$ alloy by rapid solidification and HIP treatment, Intermetallics, 27 (2012) 14-20.

15. W.Y. Kim, H. Tanaka, A. Kasama, S. Hanada, Microstructure and room temperature fracture toughness of $\mathrm{Nbss} / \mathrm{Nb}_{5} \mathrm{Si}_{3}$ in situ composites, Intermetallics, 9 (2001) 827-834. 